\title{
Contact allergic dermatitis and contact urticaria due to topical ophthalmic preparations
}

\author{
B F O’Donnell, I S Foulds
}

A patient with chronic glaucoma and a history of contact allergic dermatitis to topical ophthalmic $\beta$ adrenergic blocking drugs developed persistent ocular symptoms despite avoidance of $\beta$ blockers. He was further investigated for possible allergy to pilocarpine.

\section{Case report}

A 70-year-old man presented with a persistent itch involving his eyes and a stinging and burning sensation aggravated by instillation of

Table 1 Contact allergic dermatitis due to ophthalmic $\beta$ blockers

\begin{tabular}{|c|c|c|c|}
\hline$\beta$ blocker & Other $\beta$ blockers tested & Cross sensitisation & Reference \\
\hline Timolol $(1)^{\star}$ & - & & 5 \\
\hline Timolol (1) & - & & 6 \\
\hline Levobunolol (1) & - & & 7 \\
\hline Levobunolol (1) & - & & 8 \\
\hline Metoprolol (5) & $\begin{array}{l}\text { propranolol } \\
\text { practolol } \\
\text { timolol } \\
\text { atenolol } \\
\text { oxprenolol } \\
\text { pindolol } \\
\text { sotalolol }\end{array}$ & $\begin{array}{l}\text { propranolol } \\
\text { practolol } \\
\text { timolol }\end{array}$ & 9 \\
\hline Metipranolol (1) & $\begin{array}{l}\text { penbutolol } \\
\text { propranolol } \\
\text { oxprenolol } \\
\text { betaxolol } \\
\text { pindolol } \\
\text { timolol } \\
\text { hydroxypropranolol } \\
\text { metoprolol }\end{array}$ & ? penbutolol & 10 \\
\hline Befunolol (1) & $\begin{array}{l}\text { levobunolol } \\
\text { carteolol } \\
\text { betaxolol } \\
\text { timolol }\end{array}$ & levobunolol & 11 \\
\hline Befunolol (6) & timolol & & 12 \\
\hline $\begin{array}{l}\text { Befunolol (3) } \\
\text { Metipranolol (4) }\end{array}$ & $\begin{array}{l}\text { carteolol } \\
\text { timolol }\end{array}$ & & 13 \\
\hline Befunolol (1) & $\begin{array}{l}\text { timolol } \\
\text { carteolol } \\
\text { levobunolol }\end{array}$ & & 14 \\
\hline $\begin{array}{l}\text { Timolol (1) } \\
\text { Betaxolol } \\
\text { Metipranolol }\end{array}$ & $\begin{array}{l}\text { carteolol } \\
\text { levobunolol } \\
\text { atenolol } \\
\text { metoprolol } \\
\text { propranolol }\end{array}$ & & $\begin{array}{l}1 \\
\text { present case }\end{array}$ \\
\hline
\end{tabular}

^ Figures in parentheses indicate the number(s) of patients studied. \begin{abstract}
his pilocarpine eyedrops. The patient had a long history of glaucoma and had bilateral trabeculectomies carried out in 1978 . He still required therapy and had been treated with $\beta$ blockers and pilocarpine since 1984 . Treatment with $\beta$ blockers had been discontinued owing to the development of contact allergic dermatitis which apparently developed sequentially to timolol, betaxolol, and metipranolol as described previously. ${ }^{1}$ Examination revealed periorbital oedema with erythema and swelling of the lid

George Road,

B15 1PR

B F O'Donnell

Correspondence to:

Dr B F O'Donnell,

Professorial Unit, St John's

Thermatology, St

Palace Road, London

Accepted for publication

22 June 1993
\end{abstract}

margins. There was no evidence of conjunctivitis. Previous patch tests with the European standard series, a preservative series, a face and eye series, a contact lens series, and pilocarpine $4 \%$ eyedrop had shown a plus/minus reaction to benzalkonium chloride and a plus/minus reaction to pilocarpine eyedrops which contained benzalkonium chloride as a preservative. Treatment was changed to unpreserved pilocarpine eyedrops, and his eyelids treated with a mild topical corticosteroid preparation. After initial improvement in the appearance and swelling of the eyelids the patient re-presented with a recrudescence of the burning and stinging sensation of his eyes.

Patch testing with unpreserved pilocarpine (Minims 1\%, 2\%, and 4\%) was negative at 2 and 4 days. Subcutaneous and intradermal testing with unpreserved pilocarpine $4 \%$ was negative at 2,4 , and 7 days, making delayed hypersensitivity unlikely. However, prick tests showed a positive reaction with the development of a $10 \times 10 \mathrm{~mm}$ weal at 10-30 minutes. Prick tests in seven controls (three atopic, four non-atopic) resulted in small weals measuring up to $3 \mathrm{~mm}$ in diameter (four controls), or erythema only (three controls). We therefore considered that the reaction seen in our patient was significant. Pilocarpine was discontinued and substituted with levobunolol hydrochloride. The patient's ocular and periocular symptoms improved dramatically, and his intraocular pressure was $15 \mathrm{~mm} \mathrm{Hg}$ in both eyes.

\section{Comment}

It may be difficult to separate the clinical diagnoses of contact dermatitis, contact conjunctivitis, and contact urticaria owing to the heightened sensitivity in the eye and the adjacent skin. ${ }^{2}$ Contact dermatitis affecting the periocular skin may be irritant (toxic) or allergic in nature. The conjunctiva may be involved in similar processes $^{3}$ either alone or associated with cutaneous involvement, so-called dermatoconjunctivitis. The conjunctiva with its lymphoid tissue may be involved in all immune mechanisms. ${ }^{3}$ The allergic reaction is a delayed hypersensitivity response (type IV) mediated by $\mathrm{T}$ lymphocytes. Antigen sensitised $\mathrm{T}$ cells release lymphokines following secondary contact with the same antigen. Diagnosis of type IV allergy may be confirmed by relevant positive patch tests. False negative reactions occur when percutaneous absorption is inadequate, concen- 
tration of the allergen is too low, or the vehicle is inappropriate. To increase sensitivity intracutaneous injection may be carried out. If delayed hypersensitivity is suspected the results are read at 48 and 96 hours.

Various $\beta$ blocking ophthalmic preparations have been implicated in allergic contact conjunctivitis $^{4}$ and allergic contact dermatitis ${ }^{15-14}$ (Table 1). Positive allergic reactions to more than one $\beta$ blocker in the same patient have raised the question of cross sensitivity between various $\beta$ blockers, which has been demonstrated for some $\beta$ blockers ${ }^{9-11}$ and not for others. ${ }^{12-14}$ It is likely that cross sensitisation exists between certain $\beta$ blockers only, but the numbers reported to date are small.

Contact urticaria describes a particular reaction after contact with the skin or mucous membranes. The prototype is the weal and flare response, but a spectrum exists from pruritus only through weal and flare to a systemic reaction. The diagnosis of contact urticaria may be difficult when the eyes are involved. The weal and flare response may not be apparent and the diagnosis is suggested by the symptoms of burning or stinging rather than the signs which are more easily discernible on the skin elsewhere. Symptoms occur early, being precipitated by instillation of the offending substance into the eye.

Contact urticaria is classified into immunological, non-immunological, and unknown categories. ${ }^{15}$ Regardless of the mechanism the final common pathway is probably the same and eventuates in histamine and probably other mediators being released from mast cells. Immunologically triggered contact urticaria may involve IgE mediated hypersensitivity as indicated by a positive radioallergosorbent test (RAST). Prick or scratch tests will be positive in the affected individual and negative in healthy controls, in contrast to non-immunological contact urticaria which may be elicited in healthy asymptomatic individuals.

Sensitisation to pilocarpine is rarely noted, but a case each of allergic contact dermatitis and of allergic contact and photocontact dermatitis has been reported. ${ }^{16}{ }^{17}$ Contact urticaria due to pilocarpine has not, to our knowledge, previously been reported.

Our patient is of interest because in addition to type IV hypersensitivity to three ophthalmic $\beta$ blockers he developed contact urticaria to pilocarpine. He is currently using levobunolol hydrochloride to control his glaucoma without showing an adverse reaction as yet. We are grateful to Ms E Kritzinger for referring the patient, and to blockers for skin testing: Alcon, Allergan, Dispersa, Merck Sharp and Dohme, and Smith and Nephew.

1 O'Donnell BF, Foulds IS. Contact allergy to beta-blocking gents in ophthalmic preparations. Contact Dermatitis 1993 28: 121-2.

2 Herbst RA, Maibach HI. Contact dermatitis caused by allergy to ophthalmic drugs and contact lens solutions. Contact Dermatitis 1991 ; 25: 305-12.

3 Podmore P, Storrs FJ. Contact lens intolerance; allergic conjunctivitis? Contact Dermatitis 1989; 20: 98-103.

4 Cameli N, Vicenzi C, Tosti A. Allergic contact conjunctiviti due to timolol in eyedrops. Contact Dermatitis 1991; 25: 129 30 .

5 Romaguera C, Grimalt F, Vilaplana J. Contact dermatitis by timolol. Contact Dermatitis 1986; 14: 248.

6 Fernandez-Vozmediano JM, Alonso Blasi N, Romero-Cabrera MA, Carrascosa-Cerquero A. Allergic contact dermatitis to timolol. Contact Dermatitis 1986; 14: 252.

7 van der Meeren HLM, Meurs PJ. Sensitization to levobunolo eyedrops. Contact Dermatitis 1993; 28: 41-2.

8 Schultheiss E. Ueberempfindlichkeit gegenueber levobunolol. Derm Beruf Umwelt 1989; 37: 185-6.

9 Van Joost Th, Middelkamp Hup J, Ros FE. Dermatitis as a side-effect of long-term topical treatment with certain betablocking agents. Br $\mathcal{F}$ Dermatol 1979; 101 : 171-6.

10 de Groot AC, Conemans J. Contact allergy to metipranolol. Contact Dermatitis 1988; 18: 107-8.

11 Corazza M, Virgili A, Mantovani L, Taddei Masieri L. Allergic contact dermatitis from cross-reacting beta-blocking Allergic contact dermatitis from cross-reacting

12 Kanzaki T, Kato N, Kabasawa Y, Mizuno N, Yuguchi M Majima A. Contact dermatitis due to the beta-blocker Majima A. Contact dermatitis due to the beta-blocke
befunolol in eyedrops. Contact Dermatitis 1988; 19: 388 .

13 Gailhofer G, Ludvan M. 'Beta-blockers': sensitizers in periorbital allergic contact dermatitis. Contact Dermatitis 1990 23: 262 .

14 Mancuso G. Allergic contact dermatitis due to befunolol in eyedrops. Contact Dermatitis 1992; 27: 198

15 Greaves MW, Kaplan AP. Urticaria and angioedema. In Samter M, Talmage DW, Frank MM, Frank Austen $K$ Claman HN, eds. Immunological diseases. 4th ed. Boston Toronto: Little, Brown, 1988: 1187-204.

16 Ortiz FJ, Postigo C, Ivars J, Ortiz PL, Merino V. Allergic contact dermatitis from pilocarpine and thimerosal. Contact Dermatitis 1991; 25: 203-4.

17 Helton J, Storrs FJ. Pilocarpine allergic contact and photocontact dermatitis. Contact Dermatitis 1991; 25: 133-4.
Bristol Eye Hospital H B Hoh

$M$ J Menage

C Dean-Hart

Correspondence to:

Dr H B Hoh, Bristol Eye Hospital, Lower Maudlin Street, Bristol BS1 2LX.

Accepted for publication 15 June 1993
Cilia may be passively introduced into the eye during a penetrating injury and are often well tolerated in the anterior chamber (AC). The decision to surgically remove the cilium is difficult and must be based on the individual clinical situation and the possible consequences of leaving organic material in the AC.
We report a case of late development of an implantation cyst from an intraocular cilium.

\section{Case report}

A 16-year-old male presented after striking his right eye on the corner of a cardboard box. His 